\title{
An Extremely Rare Cause of Dyspnea on Exertion: Bronchial Atresia
}

\author{
Efor Dispnesinin Çok Nadir Bir Nedeni: Bronş Atrezisi
}

Fatma Tokgoz Akyil', Ahmet Topbas', Mustafa Akyı ${ }^{2}$

\section{Abstract}

Congenital bronchial atresia (CBA) is a rare congenital airway malformation that is caused by an interruption to a proximal lobar, the segmental or subsegmental bronchus, hyperinflation and mucoid impaction distal to the atresic bronchus. Patients may be asymptomatic, or a cough, shortness of breath or recurrent infection may be encountered. We present here the case of a 21 -year-old male who presented with exertional dyspnea and cough on exertion, and who was diagnosed with congenital bronchial atresia.

Key words: Congenital bronchial atresia, dyspnea, mucocele.

\section{Özet}

Konjenital bronş atrezisi lober, segmenter veya subsegmenter bronşların atrezik sonlanması ve bu nedenle distalde oluşan havalanma artışı ve mukus birikimi ile karakterizedir. Hastalar asemptomatik olabileceği gibi; nefes darlığı, öksürük ve rekürren enfeksiyonlar ile başvurabilir. Bu olgu sunumunda, ağır eforla ortaya çıkan nefes darlığı ve öksürük nedeniyle başvuran ve konjenital bronş atrezisi tanısı konulan 21 yaşında bir erkek hasta nadir görülmesi nedeniyle sunulmuştur.

Anahtar Sözcükler: Dispne, konjenital bronş atrezisi, mucocele.

\footnotetext{
'Department of Chest Diseases, Çanakkale Mehmet Akif Ersoy State Hospital, Çanakkale, Turkey

2Department of Thoracic Surgery, Çanakkale Mehmet Akif Ersoy 'Çanakkale Mehmet Akif Ersoy Devlet Hastanesi, Göğüs Hastalıkları Kliniği, Çanakkale

State Hospital, Çanakkale, Turkey

Submitted (Başvuru tarihi): 31.10.2019 Accepted (Kabul tarihi): 24.01.2020

Correspondence (iletişim): Fatma Tokgoz Akyil, Department of Chest Diseases, Çanakkale Mehmet Akif Ersoy State Hospital, Çanakkale, Turkey

e-mail: fatmatokgoz86@gmail.com 
Congenital bronchial atresia (CBA) is a rare congenital airway malformation caused by the interruption of a proximal lobar, segmental or subsegmental bronchus and mucoid impaction, distal to the atresic bronchus. It is more commonly reported in males, with an estimated prevalence of 1.2 cases per 100,000 (1-3).

The most frequently involved segments are the left apicoposterior segment and the left lower lobe, with estimated rates of $64 \%$ and $14 \%$, respectively. Radiologically, bronchocele is a rounded branching opacity showing a mucus-filled bronchus, and adjacent airway trapping or emphysematous change may suggest is a suspicion of bronchial atresia. In bronchoscopy, a blinding-ending bronchus with classic radiographic features is diagnostically indicative of bronchial atresia $(4,5)$.

Patients are mostly diagnosed incidentally in their second or third decades. If the case is symptomatic, cough, shortness of breath and recurrent infections may present (6). We report here on a symptomatic young male diagnosed with bronchial atresia during his military service.

\section{CASE}

A 21 -year old male presented with shortness of breath, cough and sputum on exertion. The patient had been fulfilling his conscripted military service for the past three months, and was found to experience dyspnea during heavy exercise. The patient had no additional diseases or previously diagnosed lung disease. Over the previous five years, he had been prescribed antibiotics for bronchitis on three occasions. A physical examination was normal. Spirometer forced expiratory volume in one second (FEV1)/forced vital capacity (FVC) was $83 \%$ and FEV1 was 4.66 liters (81\% of predicted). Bronchodilator reversibility was negative. On a chest roentgenogram, a finger in glove sign originating in the right hilum was noted (Figure 1). A thorax high-resolution computed tomography revealed mucoid impaction and peripheral hyperlucency (Figure 2).

In an analysis of a complete blood count, white blood cells were $13.8(4.0-10.5)(\mu \mathrm{l} / \mathrm{mlK} / \mathrm{ml})$, and C-reactive protein was $15(0-5 \mathrm{mg} / \mathrm{dl})$. Routine laboratory values were within normal limits.

Upon suspicion of a bronchial abnormality, a fiberoptic bronchoscopy was performed, and the right intermediate bronchus was divided into sole lower lobe segments. The patient was diagnosed with bronchial atresia (Figure 3), and his military service was terminated with a report of congenital bronchial atresia. The patient was educated for possible complications and close follow-up was scheduled.

\section{DISCUSSION}

This case report presents a unique cause of shortness of breath, and is highly demonstrative of bronchial atresia.

The first case of CBA was defined by Ramsay et al. in 1953, and around 100 cases is have been reported in literature to date $(4,7)$. The leading locations of involved bronchi are the apicoposterior segmental bronchus of the left upper lobe, the right upper lobe, the middle lobe and the right lower lobe, respectively [6]. Bronchial atresia may present along with other congenital lung malformations, such as congenital cystic adenomatoid malformation, bronchopulmonary sequestration, congenital lobar emphysema and lesions of mixed pathology $(1,2,6)$. In the present case, the middle lobe bronchus was affected and no coincident malformation was detected.

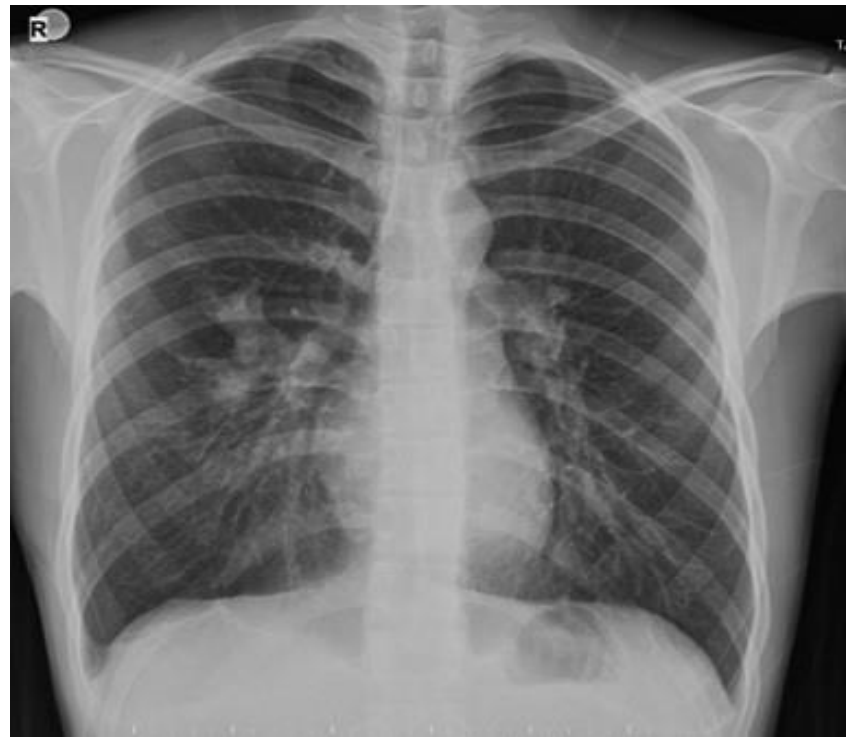

Figure 1: Chest $\mathrm{X}$-ray with finger in glove sign, originating in the right hilum

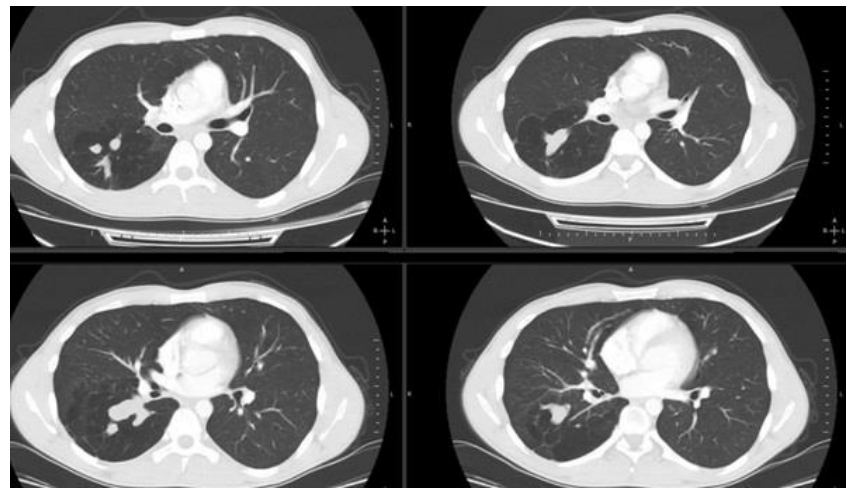

Figure 2: High-resolution computed tomography of the chest showing mucoid impaction and peripheral hyperlucency 


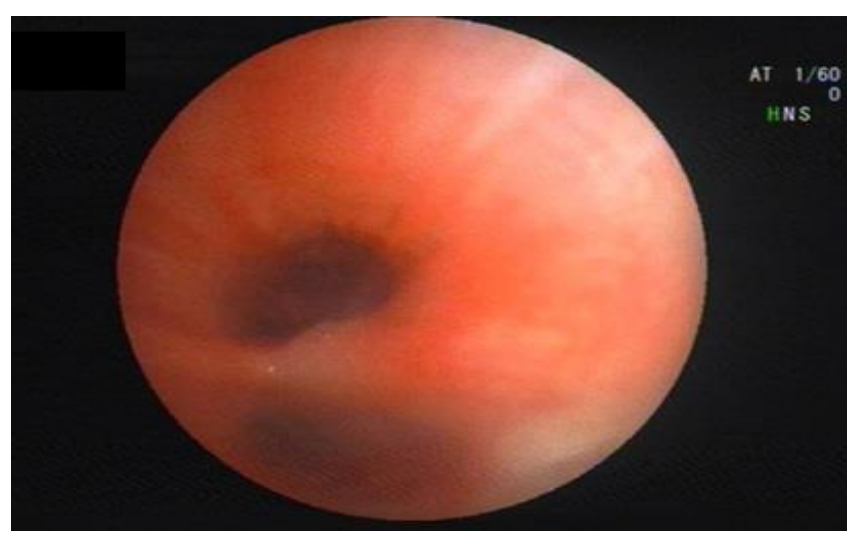

Figure 3: Endobronchial view from distal end of the right intermediate bronchus

The exact mechanism of atresia is not yet known, but the most accepted hypothesis is that the proliferating cells lose their connection with the developing respiratory bud during normal lung maturation. Another hypothesis is that a repetitive vascular insult to lung parenchyma during early fetal development leads to the obliteration of an already completed bronchus $(1,2)$.

Atretic bronchi do not communicate with the bronchial tree. Instead, the bronchoalveolar channels of Lambert, the pores of Kohn and the interbronchiolar channels permit the entry of air, but prevent air escape, acting like a one-way check valve. This results in hyperlucency and hyperinflation in the distal of the atretic segment. Generally, mucus amasses, accumulating distal to the atretic bronchus and creating a mucocele, and this accumulation may lead to recurrent infections $(7,8)$.

On a chest roentgenogram, hilar opacity in a tubular, round, ovoid or branching structure may be observed. Thorax CT reveals branching tubular or nodular opacities radiating from the hilum with a "finger-in-glove" appearance from the formation of mucoid impaction of the distal bronchus, known as a mucocele (2). Cavitary lesions and air-fluid levels may be seen distal to the atresic bronchus (8-10). In present case, a finger-in-glove sign and hyperinflation were noted.

Only one-third of diagnosed patients present with symptoms, with the most common symptoms being cough, dyspnea and recurrent infection, although wheezing, hemoptysis, chest pain and pneumothorax may also be encountered. Hyperinflation and obstructive pulmonary defects may cause dyspnea, although dyspnea is mostly reported as exertional $(4,10,11,12)$. The subject of the present case study also suffered from dyspnea on exertion. Prior to starting his military service, he had no symptoms.
Only during heavy exercise did he experience shortness of breath.

Pathologically, a diagnosis of bronchial atresia is made based on macroscopic findings, being the mucus plugging of the prominent alveoli. There are usually no acute or chronic inflammatory changes associated with bronchial atresia unless concomitant infection occurs $(1,10,12)$.

Differential diagnoses are bronchogenic cyst, lung aplasia, congenital lobar emphysema, congenital cystic adenomatiod malformation, anomalous pulmonary venous return, pulmonary sequestration, cystic fibrosis, allergic bronchopulmonary aspergillosis (ABPA), and other benign and neoplastic processes, (2) while radiological findings may suggest CBA. Bronchoscopy is not compulsory for diagnosis, but it may be necessary for the exclusion of other bronchial abnormalities (4). In the present case, radiological findings were suggestive of bronchial atresia, and were verified from the bronchoscopic findings of the atretic bronchus.

Follow-up is adequate for asymptomatic patients, while recurrent infections and complications may require surgery (2). The reported complications are recurrent infections, spontaneous pneumothorax and degradation of the pulmonary parenchyma in the long term (1). The patient reported no symptoms or infections prior to military service, and military service was terminated after the diagnosis. At 6-months follow-up, the patient is asymptomatic, and follow-up is continuing.

In conclusion, CBA is a rare airway malformation with specific exceptional radiologic findings. Other than incidental findings, patients with recurrent infections and exertional dyspnea, the clinician should consider CBA as a differential diagnosis.

\section{CONFLICTS OF INTEREST}

None declared.

\section{AUTHOR CONTRIBUTIONS}

Concept - F.T.A., A.T., M.A.; Planning and Design F.T.A., A.T., M.A.; Supervision - F.T.A., A.T., M.A.; Funding -; Materials - F.T.A., A.T., M.A.; Data Collection and/or Processing - F.T.A., A.T., M.A.; Analysis and/or Interpretation - F.T.A.; Literature Review - F.T.A.; Writing F.T.A.; Critical Review - F.T.A., A.T., M.A. 


\section{YAZAR KATKILARI}

Fikir - F.T.A., A.T., M.A.; Tasarım ve Dizayn - F.T.A., A.T., M.A.; Denetleme - F.T.A., A.T., M.A.; Kaynaklar -; Malzemeler - F.T.A., A.T., M.A.; Veri Toplama ve/veya İsleme - F.T.A., A.T., M.A.; Analiz ve/veya Yorum - F.T.A.; Literatür Taraması - F.T.A.; Yazıyı Yazan - F.T.A.; Eleştirel Inceleme - F.T.A., A.T., M.A.

\section{REFERENCES}

1. Gipson MG, Cummings KW, Hurth KM. Bronchial atresia. Radiographics 2009; 29:1531-5. [CrossRef]

2. Berrocal T, Madrid C, Novo S, Gutiérrez J, Arjonilla A, Gómez-León N. Congenital anomalies of the tracheobronchial tree, lung, and mediastinum: embryology, radiology, and pathology. Radiographics 2004; 24:e17. [CrossRef]

3. Schittny JC. Development of the lung. Cell Tissue Res 2017; 367:427-44. [CrossRef]

4. Mahajan AK, Rahimi R, Vanderlaan P, Folch E, Gangadharan $S$, Maiid A. Unique approach to diagnosing and treating congenital bronchial atresia: a case series. J Pulm Respir Med 2017; 7:2. [CrossRef]

5. Murat A, Ozdemir H, Yıldırım H, Kursad Poyraz A, Artas $\mathrm{H}$. Bronchial Atresia of Right Lower Lobe. Acta Radiol 2005; 46:480-3. [CrossRef]

6. Hutchison MJ, Winkler L. Bronchial Atresia. [Updated 2019 Jan 14]. In: StatPearls [Internet]. Treasure Island
(FL): StatPearls Publishing; 2019 Jan-.Available from: https://www.ncbi.nlm.nih.gov/books/NBK537142/

7. Zylak CJ, Eyler WR, Spizarny DL, Stone CH. Developmental lung anomalies in the adult: radiologicpathologic correlation. Radiographics 2002; 22:S25-43. [CrossRef]

8. Psathakis K, Eleftheriou D, Boulas P, Mermigkis C, Tsintiris K. Congenital bronchial atresia presenting as a cavitary lesion on chest radiography: a case report. Cases J 2009; 2:17. [CrossRef]

9. Karaman S, Deveci R, Bahçeci Erdem S, Karkiner A, Alper H, Can D. Unusual radiological sign in bronchial atresia. Turk Thorac J 2016; 17:79-81. [CrossRef]

10. Batchelor TJP, Rasburn NJ, Abdelnour-Berchtold E, Brunelli A, Cerfolio RJ, Gonzalez M, et al. Guidelines for enhanced recovery after lung surgery: recommendations of the Enhanced Recovery After Surgery (ERAS $\left.{ }^{\circledR}\right)$ Society and the European Society of Thoracic Surgeons (ESTS). Eur J Cardiothorac Surg 2019; 55:91-1 15. [CrossRef]

11. Traibi A, Seguin-Givelet A, Grigoroiu M, Brian E, Gossot D. Congenital bronchial atresia in adults: thoracoscopic resection. J Vis Surg 2017; 3:174. [CrossRef]

12. Wang Y, Dai W, Sun Y, Chu X, Yang B, Zhao M. Congenital bronchial atresia: diagnosis and treatment. Int J Med Sci 2012; 9:207-12. [CrossRef] 